Chapter 19

\title{
Current and Future Directions in Antibody-Mediated Rejection Post Kidney Transplantation
}

\author{
Rashad Hassan and Ahmed Akl \\ Additional information is available at the end of the chapter \\ http://dx.doi.org/10.5772/55001
}

\section{Introduction}

Late graft loss remains a major obstacle to successful long-term kidney allograft transplantation. The factors contributing to late graft loss include immunological (cellular and/or antibody mediated injuries) and non-immunological (donor disease, recurrent disease, peri-transplant ischemia, viral infection or drug toxicity) factors (Smith et al., 2006).

For decades, $\mathrm{T}$ cells were considered as the primary contributors to acute as well as chronic rejection after organ transplantation.

The role of antibody in rejection of transplanted organs was the subject of debate in the early days of transplantation. Peter Gorer was the first to describe the role of antibody and Peter Medwar championing cell-mediated immunity. Following the death of Gorer's in 1961, the concept of antibody-mediated rejection faded into the background. However, by 1997 demonstration of the relative sensitivity and specificity of C4d staining in peritubular capillaries in identifying antibody mediated rejection raised the hope that a rigorous morphological classification could be devised.

Allo-antibodies to HLA class I or II and other antigens expressed by endothelium cause a variety of effects on renal transplants, ranging from acute to chronic rejection, and even apparent graft acceptance (accommodation). Recognition of these conditions and appropriate therapy requires demonstration of $\mathrm{C} 4 \mathrm{~d}$ in biopsies, commonly confirmed by tests for circulating allo-antibody (Lefaucheur et al., 2010).

Pre-existing (Amico et al., 2009) or post transplant (Cantarovich et al., 2011; Lefaucheur et al., 2010) development of donor specific antibodies (DSA) lead to Acute AMR occurred in $8 \%$ of kidney transplant patients. The 5-year graft survivals of patients who had an episode of AMR were significantly worse than that of the remaining transplant population. The relative risk 
(RR) for graft loss for patients who had an episode of AMR was around 4 times as compared with patients without AMR. Importantly, even in patients without any episode of AMR, the presence of anti-HLA-DSA on the peak serum was still associated with a significantly lower graft survival as compared with patients without anti-HLA-DSA (Amico et al., 2009; Cantarovich et al., 2011; Lefaucheur et al., 2010).

The recently described entity of subclinical AMR (Gloor et al., 2006; Haas et al., 2007) in which progressive morphologic lesions are found on biopsy in the absence of overt clinical rejection may account for this different course. A recent study demonstrated that subclinical AMR is a frequent finding in patients with preformed HLA-DSA (31.1\% at 3 months) and is associated with worse GFR at 1 year (Loupy et al., 2009). These progressive lesions lead to chronic humoral rejection, first described in 2001 (Regele et al., 2002) and now recognized to be a distinct cause of late graft dysfunction and loss (Gloor et al., 2007; Regele et al., 2002).

Antibody-mediated rejection has become clinically critical because this form of rejection is usually unresponsive to conventional anti-rejection therapy, and therefore, it has been recognized as a major cause of allograft loss. Although desensitization protocols have enabled transplantation across donor-specific antibody barriers in a growing number of cases (Haas et al., 2007; Jordan, 2006), these protocols are neither consistently efficacious nor standardized. It reflects an incomplete understanding of the pathogenesis of alloantibody-induced injury as a major cause of allograft loss. Furthermore, patients treated with these modalities persist in having a high risk of multiple AMR episodes and lower graft long term survival compared to antibody free patients.

\section{Natural course}

In 1968, when kidney transplant patients were first examined for the development of antibodies after graft failure, antibodies were detected in 11 (38\%) of 29 patients who had rejected their grafts (Morris et al., 1969).

The fact that some patients in desensitization protocols developed AMR and others with similar levels of DSA at baseline did not, has remained unexplained due to the lack of detailed studies of these patients post transplant. Burns et al. (Burns et al., 2008) aimed to define the natural history of AMR in highly sensitized patients undergoing positive cross-match kidney transplantation. They found that the serum DSA level after transplantation was the major determinant of AMR. Patients who developed high levels of DSA within the first month after transplantation almost invariably developed acute humoral rejection (AHR), whereas those who maintained low levels were rejection-free. Importantly, more than half of the patients who had high levels of DSA at baseline did not develop high levels of DSA after transplantation. Almost all patients, including those who developed AMR, had a significant decrement or even disappearance of DSA early after transplantation (Gloor et al., 2004; Zachary et al., 2005). This finding that increases in DSA levels in AMR may be transient and self-limited in many patients presents difficulties in assessing the effectiveness of therapy aimed at treating AMR. 
During the $12^{\text {th }}$ International Histocompatibility workshop, a multicenter prospective study was initiated to test patients with functioning kidney transplants once for HLA antibodies post-transplantation. The 806 patients without HLA antibodies, had a subsequent 4 year graft survival of $81 \%$, compared with $58 \%$ for 158 patients with HLA antibodies [the presence of anti-HLA antibodies led to $5 \%$ allograft loss every year; therefore, after 4 years, $20 \%$ of the grafts will be lost ]( Terasaki et al., 2007).

Among 512 patients followed for 1 year post-testing in Sao Paulo, 12\% of antibody positive patients lost their grafts, whereas graft failure occurred in only $5.5 \%$ of those without HLA antibodies ( $\mathrm{P}=0.03$ ) (Campos et al., 2006). These results have been updated, demonstrating that at 3 years post-transplantation, patients without HLA antibodies had a $94 \%$ survival rate compared with 79\% for those with HLA class II antibodies (Gerbase-DeLima et al., 2007).

In a large multicentre trial, HLA-specific antibodies were detected in $21 \%$ of patients with renal allografts and $14-23 \%$ of patients with heart, liver or lung allografts (Terasaki \& Ozawa, 2004). Of 2,278 renal-allograft recipients who were followed prospectively, graft failure at 1 year occurred more frequently in patients who developed alloantibodies than in those who did not (8.6\% versus 3.0\%). Several studies have reported that de novo antibodies that are specific for graft HLA class I and class II molecules are a risk factor for premature graft loss as a consequence of renal and cardiac chronic arteriopathy (Michaels et al., 2003; Pelletier et al., 2002; Piazza et al., 2001).

For example, during a 5-year follow-up period, donor-reactive antibodies were present in $51 \%$ of patients with graft failure compared with $2 \%$ of stable control individuals. The presence of antibodies preceded graft failure in $60 \%$ of cases (Worthington et al., 2003). Worthington et al (Worthington et al., 2001) showed that among 12 patients who developed ELISA-detected HLA antibodies post-transplantation, $92 \%$ of the grafts failed, whereas among the 64 patients who remained negative, only $11 \%$ of the grafts failed $(\mathrm{P}<0.001)$.

So, circulating HLA-specific antibodies are typically present months to years before graft dysfunction, indicating that antibody-mediated graft injury might be slow to develop.

\section{Pathogenesis and mechanism}

The pathogenesis of late renal allograft loss is heterogeneous and difficult to diagnose.

How alloantibody and complement activation promote glomerulopathy, arteriopathy and fibrosis is incompletely clear. Only in the past 7 years, a potential role of alloantibodies for chronically deteriorating graft function has been postulated.

Alloantibodies are now appreciated as important mediators of acute and chronic rejection, differing in pathogenesis, or "nature," from T cell-mediated rejection.

Alloantibodies preferentially attack a different "location," namely the peritubular and glomerular capillaries, in contrast to T cells, which characteristically infiltrate tubules and arterial endothelium. 
Antibody-mediated rejection generally has a worse prognosis and requires different approaches to treatment and prevention than the usual T cell-mediated rejection.

Antibody induces rejection acutely through the fixation of complement, resulting in tissue injury and coagulation. In addition, complement activation recruits macrophages and neutrophils, causing additional endothelial injury. Antibody and complement also induce gene expression by endothelial cells, which is thought to remodel arteries and basement membranes, leading to fixed and irreversible anatomical lesions that permanently compromise graft function.

\subsection{Antigenic targets}

The main antigenic targets of antibody-mediated rejection are MHC molecules (both class I and class II) (Erlich et al., 2001) and the ABO blood-group antigens (Race \& Sanger, 1958). MHC class I molecules are found at the surface of all nucleated cells, including endothelial cells. By contrast, the distribution of MHC class II molecules is more limited. These molecules are constitutively expressed at the surface of B cells, dendritic cells (DCs) and microvascular endothelial cells (the last applies to humans but not mice) and are expressed by other cells depending on the stimuli that they have been exposed to and their transcriptional activation. The extreme polymorphism of MHC class I and class II polypeptides (more than 1,600 alleles in humans) aids their main function, which is antigen presentation to T cells.

Production of HLA specific alloantibodies depends on exposure to HLA molecules as a consequence of pregnancy, blood transfusion or transplantation. These antibodies are mainly of the IgG class. Blood-group antigens, most importantly the A and B antigens, are carbohydrate epitopes on glycolipids and glycoproteins that are present at the surface of most tissues, including erythrocytes and endothelial cells. Antibodies that are specific for A or B antigens arise 'naturally' in normal individuals who are not of the A and/or B blood group in response to antigens from the environment, and they are usually of the IgM class (Colvin \& Smith, 2005).

Antibodies to class I MHC antigens can stimulate endothelial and smooth muscle proliferation and expression of FGF receptors (Bian \& Reed, 2001). Soluble terminal complement components (C5b-9) trigger the production of FGF and PDGF by endothelial cells (Benzaquen et al., 1994). Thus antibodies and activated complement might induce gene products that promote endothelial activation and injury with consequent basement membrane duplication and arterial smooth muscle proliferation and thickening until finally, the characteristic atherosclerosis lesion of chronic rejection results in obstruction (Jin et al., 2002; Reed, 2003).

In addition to MHC molecules and blood-group antigens, minor histocompatibility antigens might also be targets of antibody-mediated rejection. Minor histocompatibility antigens, which were originally defined in mice by their ability to cause prompt skin-graft rejection, are also thought to be relevant as targets of graft-versus-host disease and as tumor antigens (Chao, 2004). In animal studies, non-MHC-specific antibodies can cause endothelial-cell apoptosis and graft rejection (Derhaag et al., 2000; Wu et al., 2002).

However, in humans, the molecular characterization of these antigens is limited. 
MICA (MHC-class-I-polypeptide-related sequence A), one of the few potential endothelialcell surface alloantigens, has been defined at the molecular level (Kooijmans-Coutinho et al., 1996).

MICA is a polymorphic non-classical MHC molecule. Antibody that is specific for MICA (MHC-class-I-polypeptide-related sequence A) can be detected in renal-allograft recipients and is associated with later rejection and graft loss (Mizutani et al., 2005; Sumitran-Holgersson et al., 2002) that was demonstrated by Zou and coworkers (Zou et al., 2007) who found that antibodies against minor histocompatibility antigens such as MICA may be associated with a poorer graft outcome.

Antibodies that recognize self-proteins might also contribute to graft injury. For example, autoantibody that is specific for the angiotensin II type 1 receptor, which is expressed by vascular smooth muscle, has been associated with severe hypertension, graft dysfunction and fibrinoid arterial necrosis of human renal allografts (Dragun et al., 2005).

Several studies have shown that circulating anti-HLA class I or II antibodies, either donor reactive (Worthington et al., 2003; Hourmant et al., 2005) or de novo non-donor reactive (Hourmant et al., 2005; Terasaki \& Ozawa, 2005), are found in a substantial fraction of renal allograft recipients, and these are associated with later graft loss. Retrospective studies demonstrated that de novo appearance of DSA was associated with poor graft outcome (Colvin, 2007). One study in more than 2000 patients prospectively established the risk of circulating alloantibodies for graft survival after 1 and 2 years (Terasaki \& Ozawa, 2005).

\subsection{B- lymphocytes}

B cells are not just plasma cell precursors, but represent an important population of antigen-presenting cells particularly efficient in the situation of a sensitized recipient, because they have specific immunoglobulin as an antigen-specific receptor on their surface, which leads to efficient uptake and presentation of donor antigens to $\mathrm{T}$ cells (Noorchashm et al., 2006). Indeed, an increased frequency of alloantigen-specific B cells in sensitized recipients has been reported (Zachary et al., 2007). Therefore, targeting these B cells will also interfere with activation of indirectly allo-reactive $\mathrm{T}$ cells, which play an important role in chronic allograft rejection.

In sensitized allograft recipients with DSA, sensitization has always occurred on the level of $\mathrm{B}$ and T cells; because B cells need T help to produce alloantibodies of IgG isotype as measured by the Luminex technology. Therefore, a combined pathogenesis of rejection must always be postulated, even if not all the pathologic criteria are fulfilled (Fehr et al., 2009).

However, failure to demonstrate DSA does not rule out a contribution of antibodies to the pathologic process, because absorption of antibodies by the allograft may result in a lack of circulating DSA (Martin et al., 2005). Alternatively, DSA against non-HLA antigens or HLA-DP could explain the missing ELISA reactivity in the presence of increased cytotoxic anti-B-cell reactivity and ongoing antibody-mediated rejection (Arnold et al., 2005; Opelz, 2005; Zou et al., 2007). 
The combination of alloantibody, basement membrane multilamination, $\mathrm{C} 4 \mathrm{~d}$, and duplication of the GBM has been termed the "ABCD tetrad" by Solez and colleagues (Solez et al., 2007).

\subsection{Plasma cells}

During AMR, it is likely that a portion of the DSA found in the serum is due to ongoing antibody production by pre-existing plasma cells. In addition, the observed increase in DSA during AMR suggests that conversion of allospecific memory B cells to plasma cells also may play a role. Unfortunately, no studies of the activity of memory B cells during AMR exist. Despite this, several groups have developed protocols to treat AMR based on their presumed impact on either B cells or plasma cells (Stegall \& Gloor, 2010).

\subsection{Presence of antibodies with good function}

It is a common observation and "complaint" that some patients with HLA antibodies have excellent kidney graft function. The exact frequency of this occurrence has been documented to be about $20 \%$ in studies of 2658 patients with functioning grafts (Terasaki et al., 2007) Thus, at any transplant center roughly $20 \%$ of patients would likely have antibodies and good function.

According to prospective studies, when 158 patients with antibodies were followed for as long as 4 years, their graft survival was $58 \%$ as compared with $81 \%$ for 806 patients without antibodies (Terasaki et al., 2007).

Significantly, the presence of antibodies did not foretell immediate or certain graft failure. Studies by Worthington et al. (Worthington et al., 2007) have shown that the mean time from antibody development to failure for class I antibodies was 2.7 years and 3.9 years for class II antibodies. Additionally, antibodies causing humoral rejection may not appear until as many as may reach up to 13 years (Kamimaki et al., 2007), or even after 26 years (Weinstein et al., 2005) posttransplant. The reason for this long interval between antibody appearance and graft failure is the time needed for the endothelial walls of arteries to hypertrophy and close the lumen, or for the tubules to disappear because of peritubular capillary damage produced by antibodies (Shimizu et al., 2002). In both instances, defense mechanisms could be triggered as the endothelium is damaged and repair mechanisms are triggered (Jin et al., 2005).

\section{Accommodation}

Transplantation across an $\mathrm{ABO}$ barrier, which normally precipitates hyperacute rejection, has been done successfully in many centers, using special protocols to deplete naturally occurring anti-blood group antibodies.

The phenomenon of accommodation, in which the graft acquires resistance to humoral injury and continues to function well despite the continued presence of antibody against a target 
antigen expressed on graft endothelium, is well documented in ABO-incompatible kidney transplants (Park et al., 2003; Platt, 2002).

Alexandre and colleagues (Alexandre et al., 1987) initially observed accommodation in recipients of an $\mathrm{ABO}$-incompatible renal allograft. Transient depletion of the circulating antibodies that are specific for these blood-group antigens at the time of transplantation allows immediate graft survival without hyperacute rejection.

A rebound of antibody concentrations (primarily IgM) within the first 10 days occurs together with rejection in $90 \%$ of cases. However, after 21 days, for the remaining grafts, there is no correlation between the occurrence of rejection and the antibody titre (Park et al., 2003; Shishido et al., 2001). Even if the antibody titre returns to pre-transplantation levels or higher, the grafts continue to function. It has been proposed that in these cases, complement regulatory proteins and/or other control mechanisms may interrupt the complement cascade distal to the generation of $\mathrm{C} 4 \mathrm{~d}$, so the persistence of $\mathrm{C} 4 \mathrm{~d}$ on graft endothelium represents a marker for the arrest of the complement cascade rather than ongoing complement-mediated graft injury (Williams et al., 2004).

As suggested by Platt (Platt, 2002), careful histologic and immunohistologic study may help to answer this question and address any potential role of complement in the accommodation process. Accommodation in ABO-incompatible grafts is not due to a change in the nature of the antibody or loss of the target antigen in the graft, because C4d is deposited in the renal microcirculation.

At a cellular level, accommodation may occur via multiple mechanisms, including internalization, downregulation, inactivation, and inhibition of the target antigen (Colvin \& Nickeleit, 2006; Colvin \& Smith, 2005).

Studies in mice show that, in the absence of T-cell help, B cells that are exposed to incompatible carbohydrate antigens on allografts differentiate into cells that can produce non-complementfixing antibody which potentially competes with complement-fixing antibody, and these B cells gradually become tolerant after prolonged exposure (Ogawa et al., 2004).

In HLA-mismatched grafts, alloantibodies can be found in the absence of clinical graft dysfunction, thereby fitting the definition of accommodation. However, patients with circulating HLA-specific antibody have a greater likelihood of later graft loss, indicating that, if accommodation occurs, then it is either transient or insufficient to prevent CAMR. Long-term, complete accommodation has not been documented for MHC molecules, and the phenomenon might therefore be partly determined by the nature of the antigen (Colvin \& Smith, 2005). Accommodation may have different degrees of effectiveness and stability (gradations), ranging from none (hyperacute rejection), to minimal (acute rejection), substantial (chronic rejection), or complete (stable accommodation) (Colvin, 2007). The minimal features that indicate transformation from accommodation to rejection have yet to be defined and drugs that promote more effective accommodation would potentially be useful clinically. 


\section{Stages of antibody-mediated rejection}

At a National Institutes of Health (United States) consensus conference, draft criteria were established for antibody-mediated rejection and for four theoretical stages in the development of CAMR (Takemoto et al., 2004) as shown in FIG. 1 (Colvin \& Smith, 2005).

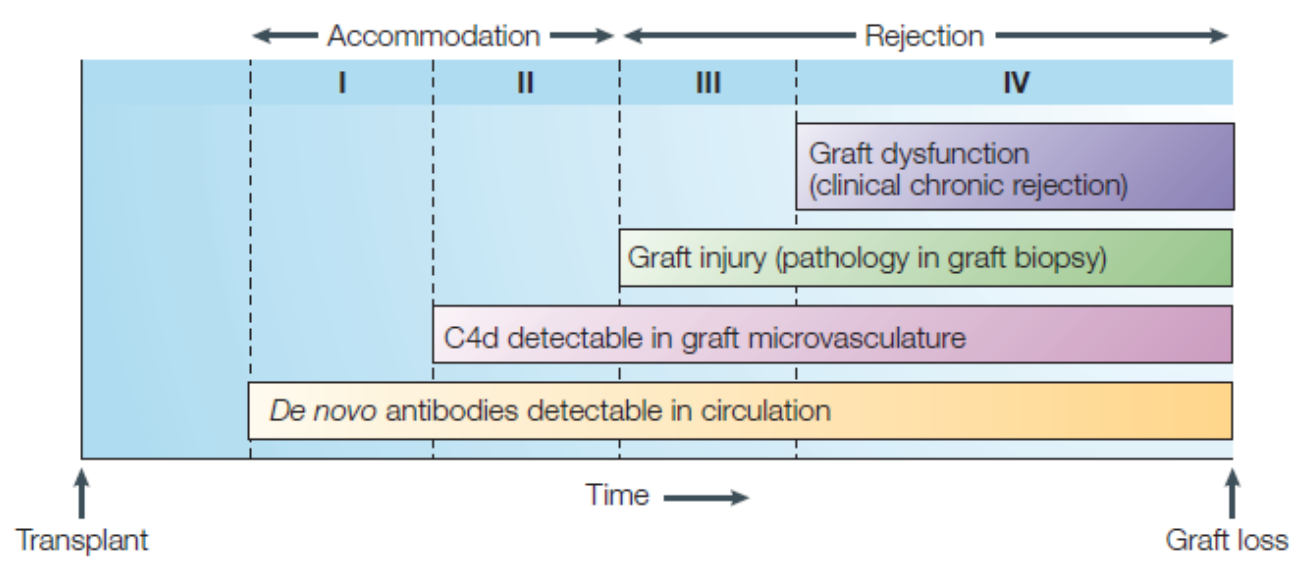

Figure 1. Proposed stages of antibody-mediated rejection (Reproduced with permission from Nature Publishing Group).

According to this model, the first evidence of an antibody-mediated response is the de novo generation of donor-reactive antibodies (stage I). In many circumstances and for unknown reasons, donor-reactive antibodies do not elicit AAMR.

The next stage (stage II) shows evidence of antibody reactivity and complement activation in the graft, with C4d deposition in peritubular or glomerular capillary endothelium. At this stage, there is no evidence of pathological or clinical injury in the graft. Both stage I and stage II fit the criteria for accommodation and are therefore not necessarily predestined to lead to graft injury. In stage III, in addition to positive staining for $\mathrm{C} 4 \mathrm{~d}$, there are identifiable pathological changes, but graft function is still normal (that is, there is subclinical rejection). Finally, in stage IV, in addition to positive staining for $\mathrm{C} 4 \mathrm{~d}$ and pathological changes, graft dysfunction occurs. The interval between stages can be long and variable, and it is not known whether progression is inexorable (Colvin \& Smith, 2005).

\section{Pathology}

The past 20 years have seen major advances in the understanding of the effects of antidonor antibodies on renal allografts at various stages after transplantation. These advances have been due in large part to pathologic examination of both early and late renal 
allograft biopsies, including both routine histologic evaluation and immunohistology to detect complement split products.

\subsection{Acute antibody mediated rejection}

As pathologists have become increasingly adept at diagnosing antibody-mediated rejection (AMR) on allograft biopsies, substantial progress has been made in the treatment of AMR and in successful renal transplantation in recipients with pre-existing antibodies against donor blood group ( $\mathrm{ABO}$ ) and/or major histocompatibility (HLA) antigens. It has become critical to develop standardized criteria for the pathological diagnosis of AMR.

The diagnostic criteria for acute humoral rejection (AMR; acute antibody-mediated rejection). Patients with AHR present with an acute loss of graft function that often arises in the first few weeks after transplantation and cannot be distinguished from cell-mediated rejection on clinical grounds (Halloran et al., 1992; Takemoto et al., 2004). AMR can also develop years after transplantation, often triggered by a decrease in immunosuppression (iatrogenic, noncompliance, or malabsorption). Presensitization is the major risk factor, but most of the patients with AMR had a negative cross-match. AMR has occurred with all immunosuppression regimens, even profoundly depleting therapy (Lorenz et al., 2004). The first clue that circulating anticlass I HLA antibody caused a different pattern of acute rejection came from the studies of Halloran's group in Edmonton (Halloran et al., 1992). These investigators showed that neutrophils in peritubular capillaries (PTC) and glomerular capillaries are strongly associated with circulating anti-donor HLA antibodies. Other features, such as fibrinoid necrosis of arteries and microthrombi, are also more common. However, none of these features is specific.

The pathology of AMR has a wide spectrum and can easily be missed by histologic criteria alone. Renal biopsies may show acute cellular rejection, acute tubular injury, or thrombotic microangiopathy. Neutrophils in capillaries are characteristically but not always found. Macrophages are now recognized as a common intracapillary cell in AMR in kidney (Tinckam et al., 2005) and heart (Lepin et al., 2006) allografts. Typically, the PTC are dilated. Fibrinoid necrosis is found in a minority of cases (approximately 10 to $20 \%$ ). A component of acute cellular rejection may also be present, as manifested by a prominent mononuclear infiltrate, tubulitis, or endarteritis. These lesions are generally not attributable to antibody alone. Treg cells (FOXP3+) are rarer in the infiltrate than in cell-mediated rejection, perhaps contributing to the poorer prognosis in AMR (Veronese et al., 2007). Microthrombi and interstitial hemorrhage also sometimes occur. The PTC and glomerular endothelium shows a variety of ultrastructural changes, including loss of fenestrations, detachment from the basement membrane, lysis, and apoptosis; complete destruction of capillaries can occur, leaving thickened laminated basement membranes (Liptak et al., 2005). Immunofluorescence (IF) curiously does not often show antibody or C3 deposition in the vessels. However, IF does show C4d in the majority of the PTC as a bright ring pattern, using a mAb in cryostat sections (Collins et al., 1999; Mauiyyedi et al., 2001, 2002). Immunohistochemistry (IHC) works in formalinfixed, paraffin-embedded tissues with a polyclonal antibody (Lorenz et al., 2004). By immunoelectron microscopy, $\mathrm{C} 4 \mathrm{~d}$ is detected on the surface of the endothelial cells and in intracytoplasmic vesicles (Regele et al., 2002). Antibodies that react to non-C4d portions of the 
C4 molecule do not show PTC deposition, arguing that what is detected in tissues is primarily C4d (Seemayer et al., 2006).

\subsection{Chronic antibody mediated rejection}

Chronic AMR is now included in the newest update of the Banff 07 classification of renal allograft pathology with the following criteria: [1]morphological changes as glomerular double contours compatible with transplant glomerulopathy (TPG) and severe PTC basement membrane multilayering, interstitial fibrosis and tubular atrophy with or without PTC loss, and fibrous intimal thickening in arteries without internal elastica duplication; [2] diffuse C4d deposition in PTCs; and [3] presence of DSA (Solez et al.,2008). Not all these criteria are always fulfilled in an individual patient at every given time point (Fehr et al., 2009).

PTC basement membrane multilayering correlates highly with TPG, and most of TPG have evidence of either C4d-positive staining or DSA. However, the proposed criteria do not apply to all situations of chronic active antibody-mediated rejection. Chronic AMR is distinct from acute AMR in that no acute inflammation (neutrophils, edema, necrosis, thrombosis) is present. However, cellular activity is often reflected by increased mononuclear cells in glomerular capillaries and PTC (Colvin, 2007). The Banff criteria require PTC C4d positivity for diagnosis of ABMR as well as microcirculation injury. However, C4d is not a sensitive marker of chronic ABMR, and in many patients with transplant glomerulopathy, C4d staining is negative in the presence of anti-HLA DSA. Therefore, the recent update of the Banff classification introduced the diagnostic category of "suspicious for ABMR." It is defined with the presence of morphologic evidence of antibodymediated tissue injury and positive anti-HLA antibody with negative C4d, or PTC C4d positivity in the absence of alloantibody (Solez et al., 2008).

\section{Markers of antibody mediated rejection}

\subsection{Histopathologic detection of C4d}

Feucht et al. (Feucht et al., 1993) in Munich showed that peritubular capillary (PTC) C4d deposition in renal transplant biopsies is strongly associated with a poor prognosis and raised the possibility that antibodies were responsible. Currently, $\mathrm{C} 4 \mathrm{~d}$ has been adopted as a marker of antibody-mediated rejection (Racusen et al., 2003). The justification for the selection of C4d, a split product of $\mathrm{C} 4$, as a marker for AMR comes from its position in the cascade of complement activation. C4d, a split product of the classical pathway of complement activation, is present covalently bound on tissue near the sites of complement activation by alloantibody, e.g., vascular endothelial cell membrane.

C4d deposition in renal peritubular capillaries is strongly associated with circulating antibody to donor HLA class I or class II antigens (Bohmig et al., 2002; Haas et al., 2006) and is currently the best single marker of complement-fixing circulating antibodies to the endothelium. 


\subsection{C4d detection pitfalls}

C4d is not a magic marker for antibody-mediated rejection and in many patients with transplant glomerulopathy. It is negative in the presence of anti-HLA DSA. Another issue with chronic active antibody-mediated rejection is non-HLA antibody induced rejection without complement fixation of $\mathrm{C} 4 \mathrm{~d}$. Moreover, it was shown in many studies that focal C4d staining was not a reliable indicator of AMR (Kayler et al., 2008), and it is not a guarantee of AMR: diffuse $\mathrm{C} 4 \mathrm{~d}$ staining can occur with no morphologic injury or impaired outcome in ABOincompatible allografts (Solez et al., 2008). Another important problem is the significance of positive C4d staining in the peritubular capillaries (PTC) and glomerular capillaries.

There are significant data to show that C4d positivity is usually long-lasting but is not permanent. C4d staining can change from negative to positive and vice versa within days to weeks. The detection of C4d signifies a humoral alloresponse in a subgroup of kidney transplants, which is often associated with signs of cellular rejection (Nickeleit et al., 2002). It is not clear how long C4d deposits persist in the absence of continued DSA production. One study reported that $\mathrm{C} 4 \mathrm{~d}$ deposits were no longer detectable on repeat biopsy performed 2-3 weeks after DSA (Mauiyyedi et al., 2002). If C4d staining misses some cases of antibodymediated injury, and the presence of alloantibody does not identify which grafts are undergoing antibody-mediated damage, we need new methods for identifying which kidneys are being damaged by alloantibody.

\subsection{Alternative markers (New diagnostic tools)}

\subsubsection{Endothelial-associated transcripts (ENDATs) as a new marker for CAMR}

Recognizing the key role of endothelial changes in AMR, it was postulated by Sis and colleagues (Sis et al., 2009) that altered expression of endothelial genes in biopsies from patients with alloantibody would identify kidneys incurring antibody-mediated damage and at risk for graft loss, whether they were $\mathrm{C} 4 \mathrm{~d}+$ or negative. They explored whether expression of endothelial genes was increased in biopsies manifesting antibody-mediated graft injury, and whether such changes could be seen in C4d negative as well as C4d positive biopsies. They identified 119 endothelial-associated transcripts (ENDATs) from literature, and studied their expression by microarrays in 173 renal allograft biopsies for cause.

Mean ENDAT expression was increased in all rejection but was higher in AMR than in T-cell-mediated rejection and correlated with histopathologic lesions of AMR, and alloantibody. Many individual ENDATs were increased in AMR and predicted graft loss. Kidneys with high ENDATs and antibody showed increased lesions of AMR and worse prognosis in comparison to controls. Only $40 \%$ of kidneys with high ENDAT expression and chronic AMR or graft loss were diagnosed by C4d positivity. High ENDAT expression with antibody predicts graft loss with higher sensitivity (77\% versus. $31 \%$ ) and slightly lower specificity ( $71 \%$ vs. $94 \%$ ) than C4d. The results were validated in independent set of 82 kidneys. They concluded that in patients with alloantibodies, abnormalities in expression of endothelial genes identify not only C4d+ AMR but some kidney transplants developing antibody associated graft injury despite negative C4d staining 
and that ENDAT changes in renal transplants occur in rejection and in other forms of renal injury, and their impact on transplant glomerulopathy and graft loss is principally in patients with circulating HLA antibodies. The elevation of the ENDATs is of value in determining which biopsies for cause in patients with antibody may have antibody-mediated injury, even when they are C4d negative. Based on their study, the combined burden of $\mathrm{C} 4 \mathrm{~d}+$ and C4d negative AMR accounts for the majority of graft losses in kidney transplants biopsied for clinical indications (17 of 26, 65\%). ENDAT expression in biopsy provides a new tool for understanding the pathogenesis of late kidney graft loss and AMR, and for predicting graft outcomes and defining AMR even in C4d negative biopsies in patients with antibodies (Sis et al., 2009).

\subsubsection{TRIB1as a new non-invasive marker for CAMR}

The discovery of novel and less invasive surrogate biomarkers of acute cellular rejection, for which urine levels of Granzyme B and FOXP3 transcripts have been shown to have diagnostic and prognostic value (Muthukumar et al., 2005; Veale et al., 2006), has proved successful. Such an approach in the case of the different causes of late graft failure would facilitate the introduction of more targeted immunosuppression and thereby improve long-term outcome. Ashton-Chess and colleagues (Ashton-Chess et al., 2008) set out to discover novel minimally invasive biomarkers of more precise histologic diagnoses of late graft scarring. Using a literature gene-set comparison approach for late graft injury, they identified TRIB1, a human homolog of Drosophila tribbles, (Grosshans \& Wieschaus, 2000) as a potentially informative biomarker. TRIB1 is a scarcely characterized member of the tribbles family that has been shown to be a potent regulator of cell signaling18 in various cells lines. It was determined that TRIB1 is expressed primarily by antigen-presenting cells (APC) and activated endothelial cells (EC). TRIB1 differs from the other minimally invasive biomarkers of transplant rejection described to date that are of T/NK cell origin, (Muthukumar et al., 2005; Seiler et al., 2007; Veale et al., 2006) in that it is expressed primarily by APC as well as EC.

They explored the potential of TRIB1 as a tissue, peripheral blood, and urine biomarker by measuring its mRNA profiles in graft biopsies, blood, and urine from healthy volunteers and kidney transplant recipients with different histologic and/or clinical diagnoses. For testing this, mRNA expression in 76 graft biopsies, 71 blood samples, and 11 urine samples were profiled from independent cohorts of renal transplant patients with different histologic diagnoses recruited at two European centers. TRIB1 but not TRIB2 or TRIB3 was found to be a potential blood and tissue (but not urine) biomarker of chronic antibody-mediated rejection. Moreover, TRIB1 mRNA in the blood was more specific and sensitive for diagnosing chronic AMR than TRIB1 mRNA in biopsies.

TRIB1 mRNA levels in peripheral blood mononuclear cells discriminated patients with chronic antibody-mediated rejection from those with other types of late allograft injury with high sensitivity and specificity, suggests TRIB1 to be a marker of an active immune response. Overall, these data support the potential use of TRIB1 as a biomarker of chronic antibodymediated allograft failure. 


\section{Management of antibody mediated rejection}

Unfortunately, no immunosuppressive standard for the prevention or therapy of alloantibody production has been established yet. Although based on very limited evidence, acute humoral rejections are frequently treated with a switch to tacrolimus, plasmapheresis or immunoadsorption, as well as T- and B-cell-depleting antibodies. However, the best therapeutic approach for $\mathrm{C} 4 \mathrm{~d}$-positive, chronic humoral kidney rejection associated with an unfavourable prognosis remains completely unclear. Neither the dose nor the best drug combination for the therapy of an established humoral rejection is based on solid evidence. Although various immunosuppressive drugs can reduce the number of acute rejection ns via inhibition of the T-cell response, only very few data are available regarding immunosuppressive drugs affecting the humoral alloresponse after organ transplantation.

\subsection{Intravenous immunoglobulins (IVIG)}

The immunomodulatory effects of IVIG are multiple, and the exact mechanisms are not elucidated. However, effective alloantibody inhibition by IVIG was shown in the context of desensitization protocols only relying on high dose IVIG treatment (Jordan et al., 2003). IVIG inhibits mixed lymphocyte reactions and induces apoptosis mainly in B cells (Toyoda et al., 2004). There are numerous proposed mechanisms how IVIG exerts its immunomodulatory action. They include modification of circulating alloantibody concentration through induction of antiidiotypic circuits, antigen binding through the Fab part of the immunoglobulin molecule, Fc receptor-mediated interaction with antigen-presenting cells to block T- and B-cell activation, and inhibition of complement activity (Jordan et al., 2006).

In vivo, IVIG reduces the number of B cells and monocytes, and it reduces CD19, CD20 and CD40 expression by B cells, thereby modulating B-cell signaling (Jordan et al., 2003). IVIG inhibits binding of donor-reactive antibodies to target cells in $\sim 80 \%$ of patients, indicating that the presence of blocking antibodies might explain the efficacy of IVIG, although the mechanism is not known (Jordan et al., 2003). Billing and colleagues (Billing et al., 2008) studied Six pediatric renal transplant recipients with CAMR and gave them four weekly doses of IVIG (1 $\mathrm{g} / \mathrm{kg}$ body weight per dose), followed by a single dose of rituximab ( $375 \mathrm{mg} / \mathrm{m} 2$ body surface area) 1 week after the last IVIG infusion. Median glomerular filtration rate during 6 months before intervention dropped by 25 (range, 11-26) $\mathrm{mL} / \mathrm{min} / 1.73 \mathrm{~m} 2(\mathrm{P}<0.05)$ and increased in response to antihumoral therapy by $21(-14$ to+30) 6 months $(\mathrm{P}<0.05)$ and by $19(-14$ to+_23) $\mathrm{mL} / \mathrm{min} / 1.73 \mathrm{~m} 212$ months $(\mathrm{P}=0.063)$ after start of treatment. Glomerular filtration rate improved or stabilized in 4 patients; the two non-responders had the highest degree of transplant glomerulopathy, the highest degree of $\mathrm{C} 4 \mathrm{~d}$ deposition in peritubular capillaries and pronounced interstitial inflammation. The treatment regimen was well tolerated. Another study conducted by Fehr and colleagues (Fehr et al., 2009) who reported four kidney allograft recipients suffering from chronic AMR 1 to 27 years post-transplant, who were treated with a combination of rituximab and intravenous immunoglobulin (IVIG) with improved kidney allograft function in all four patients, whereas donor-specific antibodies were reduced in 2 of 4 patients. 


\subsection{Rituximab}

Rituximab, a chimeric monoclonal anti-CD20 antibody directed against B cells, prevents new antibody production by depletion of $\mathrm{B}$ cells as precursors of mature plasma cells in the circulation and the lymphoid tissue \{although, some recent reports demonstrated that depletion in secondary and tertiary lymphoid structures is far less efficient and may not affect an ongoing localized humoral immune response (Genberg et al., 2006; Thaunat et al., 2008)\}, prevention of B-cell proliferation, and induction of apoptosis and lysis of B cells through complement-dependent and -independent mechanisms (Salama \& Pusey, 2006). Rituximab binds CD20 at the surface of precursor and mature B cells and leads to transient B-cell depletion, with typical B-cell recovery after $6-12$ months in more than $80 \%$ of patients, although the degree of depletion is highly variable and is observed for up to 24 months in some individuals (Sureshkumar et al., 2007).An additional potential mechanism of action of rituximab is the direct targeting of CD20-positive cells that infiltrate the graft (Steinmetz et al., 2007). Preliminary studies indicate that rituximab decreases the concentration of pre-existing and post-transplantation antibodies (Gloor et al., 2003; Vieira et al., 2004). Conclusions and extrapolations from these studies are limited, because rituximab is usually combined with other therapies in these small and uncontrolled trials. The risk of bacterial infection as a result of immunoglobulin deficiency is also an important consideration. Based on the pathophysiologic condition of this rejection process and efficacy of rituximab in B cells and antibodymediated autoimmune diseases (Eisenberg \& Albert, 2006; Levesque \& St Clair, 2008), a combination treatment with rituximab/IVIG represents a logical approach.

\subsection{Mycophenolic acid and sirolimus}

In a multicenter study, MMF in combination with cyclosporine resulted in significantly lower frequencies of HLA antibodies when compared with azathioprine and cyclosporine treatment (Terasaki \& Ozawa, 2004). Moreover, MMF was described to be effective in inhibiting primary antigen-specific antibody responses in renal transplant patients (Rentenaar et al., 2002). Heidt et al (Heidt et al., 2008) stimulated purified human B cells devoid of T cells with CD40L expressing $\mathrm{L}$ cells, or by anti-CD40mAb with or without Toll-like receptor triggering, all in the presence of B-cell activating cytokines. These three protocols resulted in various degrees of Bcell stimulation. Then, they added four commonly used immunosuppressive drugs (tacrolimus, cyclosporin, mycophenolic acid [MPA], and rapamycin) to these cultures and tested a variety of parameters of B-cell activity including proliferation, apoptosis induction, and both IgM and IgG production. They found that MPA was extremely potent in inhibiting both proliferation and immunoglobulin production. Moreover, these effects persisted when MPA was added to already activated B cells, implying that an ongoing B-cell response may be dampened by MPA, whereas calcineurin inhibitors are ineffective. MPA levels used are lower than levels that are usually achieved physiologically.

In the same in vitro experiments, rapamycin, like MMF, was described to be extremely potent in inhibiting humoral responses. Rapamycin was the most effective drug tested, as it inhibited not only B-cell proliferation and immunoglobulin production, but also inhibited the number of immunoglobulin producing cells. None of the other drugs tested were capable of decreasing 
the number of immunoglobulin producing cells. By contrast, tacrolimus and cyclosporin marginally inhibited B-cell proliferation and immunoglobulin production, and the extent of inhibition depended on the degree of the B-cell stimulation.

\subsection{Bortezomib}

While the B cell-depleting anti-CD20 antibody rituximab is increasingly incorporated in treatment protocols of humoral rejection (Faguer et al., 2007), this reagent is neither effective in eliminating antibody-producing plasma cells (PC) - either newly created from memory or naiive $B$ cells or from those that existed prior to transplant- nor does it decrease circulating antibody titers (Singh et al., 2009). For an effective blockade of alloantibody formation, a specific PC-depleting reagent would be desirable. Bortezomib (BZ), a selective inhibitor of the $26 \mathrm{~S}$ proteasome, has been approved by FDA for the treatment of relapsed multiple myeloma. Mechanisms of BZ action include inhibition of NF- $\kappa$ B and cytokine expression as well as induction of apoptosis as a result of activation of the terminal unfolded protein response (Meister et al., 2007). Susceptibility to BZ-induced apoptosis is related to the high immunoglobulin synthesis rate of PCs associated with accumulation of unfolded proteins/DRiPs inducing endoplasmatic reticulum stress (Meister et al., 2007). Moreover, BZ not only acted on the humoral response but also effectively inhibited the influx of MHC class II+ cells, monocytes/macrophages, CD8+ as well as CD4+ T cells. In animal models, Vogelbacher and colleagues (Vogelbacher et al., 2010) found that combination of Bortezomib and sirolimus inhibit the chronic active antibody-mediated rejection in experimental renal transplantation in the rat. In humans, data are lacking. In one case report, Bortezomib failed to treat CAMR even after treatment with rituximab and IVIG.

Perry and colleagues (Perry et al., 2009) described two sensitized patients with AMR treated in February 2007 using a combination of bortezomib and multiple plasmapheresis. Both patients had resolution of AMR and decreased serum DSA levels months after treatment. Neither developed transplant glomerulopathy. In a slightly different clinical setting, Everly and colleagues (Everly et al., 2008) used bortezomib to treat six patients who had combined AMR and cellular rejection occurring from 3 months to 7.5 years after transplant. All six patients showed resolution of AMR with a decrease in DSA levels after treatment. Unfortunately, three of the six patients developed transplant glomerulopathy. Flechner and coworkers (Flechner et al., 2010) treated 20 cases (16 kidney-only and 4 kidney-combined organ recipients) with AMR 19.8 months (range 1-71 months) posttransplant using a combined regimen of intravenous corticosteroids followed by a 2-week cycle on days 1-4-8-11 of plasmapheresis and $1.3 \mathrm{mg} / \mathrm{m}^{2}$ bortezomib; then $0.5 \mathrm{mg} / \mathrm{kg}$ intravenous immunoglobulin four times. They found that the bortezomib-containing regimen demonstrated activity in AMR but seems to be most effective before the onset of significant renal dysfunction (serum creatinine $<3 \mathrm{mg} / \mathrm{dL}$ ) or proteinuria $(<1 \mathrm{~g} /$ day $)$.

Compared to rituximab, Waiser and colleagues (Waiser et al., 2012) found that patients with AMR treated with bortezomib had better graft survival At 18 months after treatment $(P=0.071)$ and renal function at 9 months was superior in patients treated with bortezomib as compared to rituximab-treated patients $(\mathrm{P}=0.008)$. Whereas these early clinical experiences with protea- 
some inhibition are encouraging, the lack of controls is a major limitation in assessing true efficacy. In addition, since even successfully treated AMR can still result in the development of chronic transplant glomerulopathy, the prevention of AMR might be a more important goal of these types of therapies.

\subsection{Eculizumab (Terminal complement inhibition with eculizumab)}

Almost all episodes of AMR are accompanied by evidence of early complement activation as demonstrated by C4d staining of the peritubular capillaries (Burns et al., 2008). However, the exact role of complement in the pathogenesis of AMR is unclear. Eculizumab is a humanized monoclonal antibody with high affinity for C5 and thus blocks the activation of terminal complement. Eculizumab is approved by the FDA for the treatment of paroxysmal nocturnal hemoglobinuria. Locke et al. (Locke et al., 2009) reported the successful treatment of a patient with severe AMR using eculizumab. Stegall and colleagues reported their initial experience with eculizumab treatment at the time of transplant showing that blockade of terminal complement prevented the development of AMR in patients who developed high levels of DSA post transplant (Stegall et al., 2009). Stegall et al also examined the efficacy of eculizumab in the prevention AMR in sensitized renal transplant recipients with a positive crossmatch against their living donor (Stegall et al., 2011). The incidence of biopsy-proven AMR in the first 3 months posttransplant in 26 highly sensitized recipients of living donor renal transplants who received eculizumab posttransplant was compared to a historical control group of 51 sensitized patients treated with a similar plasma exchange-based protocol without eculizumab. The incidence of AMR was $7.7 \%$ in the eculizumab group compared to $41.2 \%$ in the control group $(\mathrm{P}=0.0031)$. Eculizumab also decreased AMR in patients who developed high levels of DSA early after transplantation that caused proximal complement activation. With eculizumab, AMR episodes were easily treated with plasma exchange reducing the need for splenectomy. On 1-year protocol biopsy, transplant glomerulopathy was found to be present in $6.7 \%$ eculizumab-treated recipients and in $35.7 \%$ of control patients $(P=0.044)$.

Taken together, these studies suggest that terminal complement activation may play a critical role in the pathogenesis of early AMR. Thus, eculizumab may provide an attractive approach to the prevention of AMR.

\subsection{Future therapies with new targets}

\subsubsection{B cells}

Memory B cells are heterogeneous but have cell-surface markers (CD24, CD27, CD43 and $\mathrm{CD79b}$ ) that are potential therapeutic targets (McHeyzer-Williams \& McHeyzer-Williams, 2005). B cells also express TACI (transmembrane activator and calcium-modulating cyclophilin-ligand interactor), BCMA (B-cell maturation antigen) and BAFF receptor (B-cell-activating factor receptor), all of which are members of the TNF-receptor family that are triggered by the ligands BAFF and APRIL (a proliferation inducing ligand), which are expressed the cell surface of DCs (Craxton et al., 2003). A soluble TACI-immunoglobulin fusion protein blocks B-cell development by inhibiting the interaction between B cells and DCs (Gross et al., 2001). 
These cell-surface markers might be useful targets to prevent the development of B cells into plasma cells.

\subsubsection{Plasma cells}

Normal plasma cells express little or no CD20 and are therefore resistant to rituximabmediated depletion. Several cell-surface molecules that are expressed by plasma cells

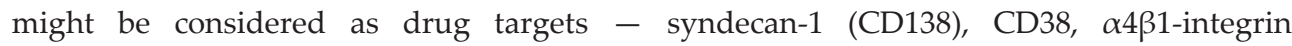
(CD49d-CD29) and CXC-chemokine receptor 4 (CXCR4) - although none of these is entirely plasma-cell specific. Plasma-cell longevity is thought to be an extrinsic phenomenon that is mediated by survival signals delivered by bone-marrow stromal cells (Colvin \& Smith, 2005). Because the transcription factors BLIMP1 (B-lymphocyte-induced maturation protein 1) and XBP1 (X-box-binding protein 1) (as well as the repression of PAX5, paired box gene 5) are required to maintain plasma-cell function, their inhibition might result in the loss of plasma-cell function (Shapiro-Shelef \& Calame, 2005).

\subsubsection{Complement antagonists}

Complement antagonists could prevent the acute pathological effects of complement activation. For example, soluble CR1 delays antibody-mediated rejection in xenograft models but is insufficient to prevent graft rejection completely (Azimzadeh et al., 2003). Other complement antagonists, such as C5-specific antibody, which blocks activation of $\mathrm{C} 5$ and formation of both $\mathrm{C} 5 \mathrm{a}$ and the MAC, are in ongoing evaluation. Transgenic expression of human complementregulatory proteins (DAF and CD59) in pigs has shown potency for preventing xenograft rejection (Menoret et al., 2004), but the relevance of these studies to allografts needs to be extended and tested.

\section{Summary}

Immunologic barriers once considered insurmountable are now consistently overcome to enable more patients to undergo organ transplantation. Alloantibodies are a substantial obstacle to short- and long-term graft survival. To prevent or reduce alloantibody titres, more insights are needed to improve our understanding of the regulation of B cells and the developmental and differentiation pathways of memory B cells and plasma cells.

Several important issues regarding AMR remain. First, the immunologic mechanisms responsible for the development of high levels of DSA are still unclear. The contribution of memory B cells versus the role of pre-existing PCs has important therapeutic implications since each may have a differential sensitivity to various agents.

Whereas several new therapeutic approaches have emerged, more extensive study and followup are needed to determine if these apparent advances will improve the outcomes of AMR. 


\section{Author details}

Rashad Hassan* and Ahmed Akl

Mansoura Urology and Nephrology Center, Egypt

\section{References}

[1] Alexandre, GPJ.; Squifflet, JP.; De Bruyère, M.; Latinne, D.; Reding, R.; Gianello, P., et al. (1987). Present experience in a series of 26 ABO-incompatible living donor renal allografts. Transplant Proc, Vol., 19; pp. 4538-4544.

[2] Amico, P.; Honger, G.; Mayr, M.; Steiger, J.; Hopfer, H. \& Schaub, S. (2009). Clinical relevance of pretransplant donor-specific HLA antibodies detected by single-antigen flow-beads. Transplantation, Vol., 87; pp. 1681-1688.

[3] Arnold, ML.; Pei, R.; Spriewald, B.\& Wassmuth, R. (2005). Anti-HLA class II antibodies in kidney retransplant patients. Tissue Antigens, Vol., 65; pp. 370-378.

[4] Ashton-Chess, J.; Giral, M.; Mengel, M.; Renaudin, K.; Foucher, Y.; Gwinner, Wet., al. (2008). Tribbles-1 as a Novel Biomarker of Chronic Antibody-Mediated Rejection. J Am Soc Nephrol, Vol., 19; pp. 1116-1127.

[5] Azimzadeh, A.; Zorn, GL 3rd.; Blair, KS.; Zhang, JP.; Pfeiffer, S.; Harrison, RA., et al. (2003). Hyperacute lung rejection in the pig to-human model. 2. Synergy between soluble and membrane complement inhibition. Xenotransplantation, Vol., 10; pp. 120 131.

[6] Benzaquen, LR.; Nicholson-Weller, A. \& Halperin, JA. (1994). Terminal complement proteins C5b-9 release basic fibroblast growth factor and platelet-derived growth factor from endothelial cells. J Exp Med, Vol., 179; pp. 985-992.

[7] Bian, H. \& Reed, EF. (2001). Anti-HLA class I antibodies transduce signals in endothelial cells resulting in FGF receptor translocation, downregulation of ICAM-1 and cell proliferation. Transplant Proc, Vol., 33; pp. 311.

[8] Billing, H.; Rieger, S.; Ovens, J.; Süsal, C.; Melk, A.; Waldherr, R., et al. (2008). Successful treatment of chronic antibody-mediated rejection with IVIG and rituximab in pediatric renal transplant recipients. Transplantation, Vol., 86; pp. 1214-1221.

[9] Bohmig, GA.; Exner, M.; Habicht, A.; Schillinger, M.; Lang, U.; Kletzmayr, J., et al. (2002). Capillary C4d deposition in kidney allografts: A specific marker of alloantibody-dependent graft injury. J Am Soc Nephrol, Vol., 13; pp. 1091-1099. 
[10] Burns, JM.; Cornell, LD.; Perry, DK.; Pollinger, HS.; Gloor, JM.; Kremers, WK., et al. (2008). Alloantibody levels and acute humoral rejection early after positive crossmatch kidney transplantation. Am J Transplant, Vol., 8; pp. 2684-2694.

[11] Campos, EF.; Tedesco-Silva, H.; Machado, PG.; Franco, M.; Medina-Pestana, JO. \& Gerbase-DeLima, M. (2006). Post-transplant anti-HLA class II antibodies as risk factor for late kidney allograft failure. Am J Transplant, Vol., 6; pp. 2316-2320.

[12] Cantarovich, D.; De Amicis, S.; Akl, A.; Devys, A.; Vistoli, F.; Karam, G., et al. (2011). Posttransplant donor-specific anti-HLA antibodies negatively impact pancreas transplantation outcome. Am J Transplant, Vol., 11; pp. 2737-2746.

[13] Chao, NJ. (2004). Minors come of age: minor histocompatibility antigens and graftversus-host disease. Biol Blood Marrow Transplant, Vol., 10; pp. 215-223.

[14] Collins, AB.; Schneeberger, EE.; Pascual, MA.; Saidman, SL.; Williams, WW.; TolkoffRubin, N., et al. (1999). Complement activation in acute humoral renal allograft rejection: Diagnostic significance of C4d deposits in peritubular capillaries. J Am Soc Nephrol, Vol., 10; pp. 2208-2214.

[15] Colvin, RB. (2007). Antibody-mediated renal allograft rejection: Diagnosis and pathogenesis. J Am Soc Nephrol, Vol., 18; pp. 1046-1056.

[16] Colvin, RB. \& Nickeleit, V. (2006). Renal transplant pathology. In: Heptinstall's Pathology of the Kidney, 6th Ed., edited by Jennette JC, Olson JL, Schwartz MM, Silva FG, Philadelphia, Lippincott-Raven, pp 1347-1490.

[17] Colvin, RB. \& Smith, RN. (2005). Antibody-mediated organ-allograft rejection. Nat Rev Immunol, Vol., 5; pp. 807-817.

[18] Craxton, A.; Magaletti, D.; Ryan, EJ. \& Clark, EA. (2003). Macrophage- and dendritic cell-dependent regulation of human B-cell proliferation requires the TNF family ligand BAFF. Blood, Vol., 101; pp. 4464-4471.

[19] Derhaag, JG.; Duijvestijn, AM.; Damoiseaux, JG. \& van Breda Vriesman, PJ. (2000). Effects of antibody reactivity to major histocompatibility complex (MHC) and nonMHC alloantigens on graft endothelial cells in heart allograft rejection. Transplantation, Vol., 69; pp. 1899-1906.

[20] Dragun, D.; Müller, DN.; Bräsen, JH.; Fritsche, L.; Nieminen-Kelhä, M.; Dechend, R., et al. (2005). Angiotensin II type 1-receptor activating antibodies in renal-allograft rejection. N Engl J Med, Vol., 352; pp. 558-569.

[21] Eisenberg, R. \& Albert, D. (2006). B-cell targeted therapies in rheumatoid arthritis and systemic lupus erythematosus. Nat Clin Pract Rheumatol,Vol., 2; pp. 20-27.

[22] Erlich, HA.; Opelz, G. \& Hansen, J. (2001). HLA DNA typing and transplantation. Immunity, Vol., 14; pp. 347-356. 
[23] Everly, MJ.; Everly, JJ.; Susskind, B.; Brailey, P.; Arend, LJ.; Alloway, RR., et al. (2008). Bortezomib provides effective therapy for antibody and cell-mediated rejection. Transplantation, Vol., 86; pp. 1754-1761.

[24] Faguer, S.; Kamar, N.; Guilbeaud-Frugier, C.; Fort, M.; Modesto, A.; Mari, A., et al. (2007). Rituximab therapy for acute humoral rejection after kidney transplantation. Transplantation, Vol., 83; pp. 1277-1280.

[25] Fehr, T.; Rüsi, B.; Fischer, A.; Hopfer, H.; Wüthrich, RP. \& Gaspert, A. (2009). Rituximab and intravenous immunoglobulin treatment of chronic antibody-mediated kidney allograft rejection. Transplantation, Vol., 87(12); pp. 1837-1841.

[26] Feucht, HE.; Schneeberger, H.; Hillebrand, G.; Burkhardt, K.; Weiss, M.; Riethmuller, G., et al. (1993). Capillary deposition of C4d complement fragment and early renal graft loss. Kidney Int, Vol., 43; pp. 1333-1338.

[27] Flechner, SM.; Fatica, R.; Askar, M.; Stephany, BR.; Poggio, E.; Koo, A., et al. (2010). The role of proteasome inhibition with bortezomib in the treatment of antibodymediated rejection after kidney-only or kidney-combined organ transplantation.Transplantation, Vol., 90; pp. 1486-1492.

[28] Genberg, H.; Hansson, A.; Wernerson, A.; Wennberg, L. \& Tydén, G. (2006). Pharmacodynamics of rituximab in kidney allotransplantation. Am J Transplant, Vol., 6; pp. 2418-2428.

[29] Gerbase-DeLima, M.; Campos, EF.; Tedesco-Silva, H.; Machado, PG.; Franco, M.; Medina-Pestana, JO. (2006). Anti-HLA class II antibodies and chronic allograft nephropathy. Clin Transpl, p. 201-205.

[30] Gloor, JM.; Sethi, S.; Stegall, MD.; Park, WD.; Moore, SB.; DeGoey, S., et al. (2007). Transplant glomerulopathy: Subclinicalincidence and association with alloantibody. Am J Transplant, Vol., 7; pp. 2124-2132.

[31] Gloor, JM.; Cosio, FG.; Rea, DJ.; Wadei, HM.; Winters, JL.; Moore, SB.. et al. ( 2006). Histologic findings one year after positive crossmatch or ABO blood group incompatible living donor kidney transplantation. Am J Transplant, Vol., 6; pp. 1841-1847.

[32] Gloor, JM.; DeGoey, S.; Ploeger, N.; Gebel, H.; Bray, R.; Moore, SB., et al. (2004). Persistence of low levels of alloantibody after desensitization in crossmatch-positive living donor kidney transplantation. Transplantation, Vol., 78; pp. 221-227.

[33] Gloor, JM.; DeGoey, SR.; Pineda, AA.; Moore, SB.; Prieto, M.; Nyberg, SL., et al. (2003). Overcoming a positive crossmatch in living-donor kidney transplantation. Am J Transplant, Vol., 3; pp. 1017-1023.

[34] Gross, JA.; Dillon, SR.; Mudri, S.; Johnston, J.; Littau, A.; Roque, R., et al. (2001). TACI-Ig neutralizes molecules critical for B cell development and autoimmune disease: impaired B cell maturation in mice lacking BLyS. Immunity, Vol., 15; pp. 289 302. 
[35] Grosshans, J. \& Wieschaus, E. (2000). A genetic link between morphogenesis and cell division during formation of the ventral furrow in Drosophila. Cell, Vol., 101; pp. 523-531.

[36] Haas, M.; Montgomery, RA.; Segev, DL.; Rahman, MH.; Racusen, LC.; Bagnasco, SM., et al. (2007). Subclinical acute antibody-mediated rejection in positive crossmatch renal allografts. Am J Transpl, Vol., 7; pp. 576-585.

[37] Haas, M.; Rahman, MH.; Racusen, LC.; Kraus, ES.; Bagnasco, SM.; Segev, DL., et al. (2006). C4d and C3d staining in biopsies of ABO- and HLA-incompatible renal allografts: Correlation with histologic findings. Am J Transplant, Vol., 6; pp. 1829-1840.

[38] Halloran, PF.; Schlaut, J.; Solez, K. \& Srinivasa, NS. (1992). The significance of the anti-class I antibody response. II. Clinical and pathologic features of renal transplants with anti-class Ilike antibody. Transplantation, Vol., 53; pp. 550-555.

[39] Heidt, S.; Roelen, DL.; Eijsink, C.; van Kooten, C.; Claas, FH. \& Mulder, A. (2008). Effects of immunosuppressive drugs on purified human B cells: evidence supporting the use of MMF and rapamycin. Transplantation, Vol., 86; pp. 1292-1300.

[40] Hourmant, M.; Cesbron-Gautier, A.; Terasaki, PI.; Mizutani, K.; Moreau, A.; Meurette, A., et al. (2005). Frequency and clinical implications of development of donorspecific and non-donor-specific HLA antibodies after kidney transplantation. J Am Soc Nephrol, Vol., 16; pp. 2804-2812.

[41] Jin, YP.; Jindra, PT.; Gong, KW.; Lepin, EJ. \& Reed EF,. (2005). Anti-HLA class I antibodies activate endothelial cells and promote chronic rejection. Transplantation, Vol., 79(3 suppl); S19-21.

[42] Jin, YP.; Singh, RP.; Du, ZY.; Rajasekaran, AK.; Rozengurt, E. \& Reed, EF. (2002). Ligation of HLA class I molecules on endothelial cells induces phosphorylation of Src, paxillin, and focal adhesion kinase in an actin-dependent manner. J Immunol, Vol., 168; pp. 5415-5423.

[43] Jordan, S. (2006). IVIG vs. plasmapheresis for desensitization: which is better? Am J Transpl, Vol., 6; pp. 1510-1511.

[44] Jordan, SC.; Vo, AA.; Peng, A.; Toyoda, M. \& Tyan, D. (2006). Intravenous gammaglobulin (IVIG): A novel approach to improve transplant rates and outcomes in highly HLA-sensitized patients. Am J Transplant, Vol., 6; pp. 459-466.

[45] Jordan, SC.; Vo, AA.; Nast, CC. \& Tyan, D. (2003). Use of high-dose human intravenous immunoglobulin therapy in sensitized patients awaiting transplantation: The Cedars-Sinai experience. Clin Transpl, pp. 193-198.

[46] Jordan, SC.; Vo, A.; Bunnapradist, S.; Toyoda, M.; Peng, A.; Puliyanda, D., et al. (2003). Intravenous immune globulin treatment inhibits crossmatch positivity and allows for successful transplantation of incompatible organs in living-donor and cadaver recipients. Transplantation, Vol., 76; pp. 631-636. 
[47] Kamimaki, I.; Ishikura, K.; Hataya, H.; et al. (2007). A case of allograft dysfunction with antibody-mediated rejection developing $13 \mathrm{yr}$ after kidney transplantation. Clin Transplant, Vol., 21(suppl 18); pp. 60.

[48] Kayler, LK.; Kiss, L.; Sharma, V.; Mohanka, R.; Zeevi, A.; Girnita, A., et al. (2008). Acute renal allograft rejection: Diagnostic significance of focal peritubular capillary C4d. Transplantation, Vol., 85; pp. 813-820.

[49] Kooijmans-Coutinho, MF.; Hermans, J.; Schrama, E.; Ringers, J.; Daha, MR.; Bruijn, JA., et al. (1996). Interstitial rejection, vascular rejection, and diffuse thrombosis of renal allografts. Predisposing factors, histology, immunohistochemistry, and relation to outcome. Transplantation, Vol., 61; pp. 1338-1344.

[50] Lefaucheur, C.; Loupy, A.; Hill, GS.; Andrade, J.; Nochy, D.; Antoine, C., et al. (2010). Preexisting donor-specific HLA antibodies predict outcome in kidney transplantation. J Am Soc Nephrol, Vol., 21; pp. 1398-1406.

[51] Lepin, EJ.; Zhang, Q.; Zhang, X.; Jindra, PT.; Hong, LS.; Ayele, P., et al. (2006). Phosphorylated S6 ribosomal protein: A novel biomarker of antibody-mediated rejection in heart allografts. Am J Transplant, Vol., 6; pp. 1560-1571.

[52] Levesque, MC. \& St Clair, EW. (2008). B cell-directed therapies for autoimmune disease and correlates of disease response and relapse. J Allergy Clin Immunol, Vol., 121; pp. 13-21.

[53] Liptak, P.; Kemeny, E.; Morvay, Z.; Szederkenyi, E.; Szenohradszky, P.; Marofka, F., et al.(2005). Peritubular capillary damage in acute humoral rejection: An ultrastructural study on human renal allografts. Am J Transplant, Vol., 5; pp. 2870-2876.

[54] Locke, JE.; Magro, CM.; Singer, AL.; Segev, DL.; Haas, M.; Hillel, AT., et al. (2009). The use of antibody to complement protein C5 for salvage treatment of severe antibody-mediated rejection. Am J Transplant, Vol., 9; pp. 231-235.

[55] Lorenz, M.; Regele, H.; Schillinger, M.; Exner, M.; Rasoul-Rockenschaub, S.; Wahrmann, M., et al. (2004). Risk factors for capillary C4d deposition in kidney allografts: Evaluation of a large study cohort. Transplantation, Vol., 78; pp. 447-452.

[56] Loupy, A.; Suberbielle-Boissel, C.; Hill, GS.; Lefaucheur, C.; Anglicheau, D.;Zuber, J., et al. (2009). Outcome of subclinical antibodymediated rejection in kidney transplant recipients with preformed donor-specific antibodies. Am J Transplant, Vol., 9; pp. 2561-2570.

[57] Martin, L.; Guignier, F.; Bocrie, O.; D'Athis, P.; Rageot, D.; Rifle, G., et al. (2005). Detection of anti-HLA antibodies with flow cytometry in needle core biopsies of renal transplants recipients with chronic allograft nephropathy. Transplantation, Vol., 79; pp. 1459-1461.

[58] Mauiyyedi, S.; Crespo, M.; Collins, AB.; Schneeberger, EE.; Pascual, MA.; Saidman, SL., et al. (2002). Acute humoral rejection in kidney transplantation: II. Morphology, 
immunopathology, and pathologic classification. J Am Soc Nephrol, Vol., 13; pp. 779-787.

[59] Mauiyyedi, S.; Pelle, PD.; Saidman, S.; Collins, AB.; Pascual, M.; Tolkoff-Rubin, NE., et al. (2001). Chronic humoral rejection: Identification of antibody-mediated chronic renal allograft rejection by C4d deposits in peritubular capillaries. J Am Soc Nephrol, Vol., 12; pp. 574-582.

[60] McHeyzer-Williams, LJ. \& McHeyzer-Williams, MG. (2005). Antigen-specific memory B cell development. Annu Rev Immunol, Vol., 23; pp. 487-513.

[61] Meister, S.; Schubert, U.; Neubert, K.; Herrmann, K.; Burger, R.; Gramatzki, M., et al. (2007). Extensive immunoglobulin production sensitizes myeloma cells for proteasome inhibition. Cancer Res, Vol., 67; pp. 1783-1792.

[62] Ménoret, S.; Plat, M.; Blancho, G.; Martinat-Botté, F.; Bernard, P.; Karam, G., et al. (2004). Characterization of human CD55 and CD59 transgenic pigs and kidney xenotransplantation in the pig-to-baboon combination. Transplantation, Vol., 77; pp. 14681471.

[63] Michaels, PJ.; Espejo, ML.; Kobashigawa, J.; Alejos, JC.; Burch, C.; Takemoto, S., et al. (2003). Humoral rejection in cardiac transplantation: risk factors, hemodynamic consequences and relationship to transplant coronary artery disease. J Heart Lung Transplant, Vol., 22; pp. 58-69.

[64] Mizutani, K.; Terasaki, P.; Rosen, A.; Esquenazi, V.; Miller, J.; Shih, RN., et al. (2005). Serial ten-year follow-up of HLA and MICA antibody production prior to kidney graft failure. Am J Transplant, Vol., 5; pp. 2265-2272.

[65] Morris, PJ.; Mickey, MR.; Singal, DP. \& Terasaki, PI. (1969). Serotyping for homotransplantation, XXII: specificity of cytotoxic antibodies developing after renal transplantation. Br Med J, Vol., 1; pp. 758-759.

[66] Muthukumar, T.; Dadhania, D.; Ding, R.; Snopkowski, C.; Naqvi, R.; Lee, JB., et al. (2005). Messenger RNA for FOXP3 in the urine of renal-allograft recipients. N Engl J Med, Vol., 353; pp. 2342-2351.

[67] Nickeleit, V.; Zeiler, M.; Gudat, F.; Thiel, G. \& Mihatsch, MJ. (2002). Detection of the complement degradation product $\mathrm{C} 4 \mathrm{~d}$ in renal allografts: diagnostic and therapeutic implications. J Am Soc Nephrol, Vol., 13; pp. 242-251.

[68] Noorchashm, H.; Reed, AJ.; Rostami, SY.; Mozaffari, R.; Zekavat, G.; Koeberlein, B., et al. (2006). B cell-mediated antigen presentation is required for the pathogenesis of acute cardiac allograft rejection. J Immunol, Vol., 177; pp. 7715-7722.

[69] Ogawa, H.; Mohiuddin, MM.; Yin, DP.; Shen, J.; Chong, AS. \& Galili, U. (2004). Mouse-heart grafts expressing an incompatible carbohydrate antigen. II. Transition from accommodation to tolerance. Transplantation, Vol., 77; pp. 366-373. 
[70] Opelz, G. (2005). Collaborative Transplant Study. Non-HLA transplantation immunity revealed by lymphocytotoxic antibodies. Lancet, Vol., 365; pp. 1570-1576.

[71] Park, WD.; Grande, JP.; Ninova, D.; Nath, KA.; Platt, JL.; Gloor, JM., et al. (2003). Accommodation in ABO-incompatible kidney allografts, a novel mechanism of self-protection against antibody-mediated injury. Am J Transplant, Vol., 3; pp. 952-960.

[72] Pelletier, RP.; Hennessy, PK.; Adams, PW.; VanBuskirk, AM.; Ferguson, RM. \& Orosz, CG. (2002). Clinical significance of MHC-reactive alloantibodies that develop after kidney or kidney-pancreas transplantation. Am J Transplant, Vol., 2; pp. 134-141.

[73] Perry, DK.; Burns, JM.; Pollinger, HS.; Amiot, BP.; Gloor, JM.; Gores, GJ., et al. (2009). Proteasome inhibition causes apoptosis of normal human plasma cells preventing alloantibody production. Am J Transplant, Vol., 9; pp. 201-209.

[74] Piazza, A.; Poggi, E.; Borrelli, L.; Servetti, S.; Monaco, PI.; Buonomo, O., et al. (2001). Impact of donor-specific antibodies on chronic rejection occurrence and graft loss in renal transplantation: posttransplant analysis using flow cytometric techniques. Transplantation, Vol., 71; pp. 1106-1112.

[75] Platt, JL. (2002). C4d and the fate of organ allografts. J Am Soc Nephrol, Vol., 13; pp. 2417-2419.

[76] Race, RR. \& Sanger, R. (1958). Blood Groups in Man (Blackwell Scientific, Oxford,).

[77] Racusen, LC.; Colvin, RB.; Solez, K.; Mihatsch, MJ.; Halloran, PF.; Campbell, PM., et al. (2003). Antibody-mediated rejection criteria - an addition to the banff 97 classification of renal allograft rejection. Am J Transpl, Vol., 3; pp. 708-714.

[78] Reed, EF. (2003). Signal transduction via MHC class I molecules in endothelial and smooth muscle cells. Crit Rev Immunol, Vol., 23; pp. 109-128.

[79] Regele, H.; Bohmig, GA.; Habicht, A.; Gollowitzer, D.; Schillinger, M.; Rockenschaub, S., et al. (2002). Capillary deposition of complement split product C4d in renal allografts is associated with basement membrane injury in peritubular and glomerular capillaries: A contribution of humoral immunity to chronic allograft rejection. J Am Soc Nephrol, Vol., 13; pp. 2371-2380.

[80] Rentenaar, RJ.; van Diepen, FN.; Meijer, RT.; Surachno, S.; Wilmink, JM.; Schellekens, PT., et al. (2002). Immune responsiveness in renal transplant recipients: Mycophenolic acid severely depresses humoral immunity in vivo. Kidney Int, Vol., 62; pp. 319-328.

[81] Salama, AD. \& Pusey, CD. (2006). Drug insight: Rituximab in renal disease and transplantation. Nat Clin Pract Nephrol, Vol., 2; pp. 221-230.

[82] Seemayer, CA.; Gaspert, A.; Nickeleit, V. \& Mihatsch, MJ. (2006). C4d staining of renal allograft biopsies: Comparative analysis of different staining techniques. Nephrol Dial Transplant, Vol., 22; pp. 568-576. 
[83] Seiler, M.; Brabcova, I.; Viklicky, O.; Hribova, P.; Rosenberger, C.; Pratschke, J., et al. (2007). Heightened expression of the cytotoxicity receptor NKG2D correlates with acute and chronic nephropathy after kidney transplantation. Am J Transplant, Vol., 7; pp. 423-433.

[84] Shapiro-Shelef, M. \& Calame, K. (2005). Regulation of plasma-cell development. Nature Rev Immunol, Vol., 5; pp. 230-242.

[85] Shimizu, A.; Yamada, K.; Sachs, DH. \& Colvin, RB. (2002). Persistent rejection of peritubular capillaries and tubules is associated with progressive interstitial fibrosis. Kidney Int, Vol., 61; pp. 1867-1879.

[86] Shishido, S.; Asanuma, H.; Tajima, E.; Hoshinaga, K.; Ogawa, O.; Hasegawa, A., et al. ABO-incompatible living-donor kidney transplantation in children. Transplantation. $2001 ; 72,1037-42$.

[87] Singh, N.; Pirsch, J. \& Samaniego, M. (2009). Antibody-mediated rejection: treatment alternatives and outcomes. Transplant Rev (Orlando), Vol., 23; pp. 34-46.

[88] Sis, B.; Jhangri, GS.; Bunnag, S.; Allanach, K.; Kaplan, B. \& Halloran, PF. (2009). Endothelial Gene Expression in Kidney Transplants with Alloantibody Indicates Antibody-Mediated Damage Despite Lack of C4d Staining. Am J Transplant, Vol., 9(10); pp. 2312-2323.

[89] Smith, RN.; Kawai, T.; Boskovic, S.; Nadazdin, O.; Sachs, DH.; Cosimi, AB., et al. (2006). Chronic antibody mediated rejection of renal allografts: pathological, serological and immunologic features in nonhuman primates. Am J Transplant, Vol., 6(8), pp. 1790-1798.

[90] Solez, K.; Colvin, RB.; Racusen, LC.; Haas, M.; Sis, B.; Mengel, M., et al. (2008). Banff 07 classification of renal allograft pathology: updates and future directions. Am J Transplant, Vol., 8; pp. 753-760.

[91] Solez, K.; Colvin, RB.; Racusen, LC.; Sis, B.; Halloran, PF.; Birk, PE., et al. (2007). Banff ' 05 meeting report: Differential diagnosis of chronic injury and elimination of chronic allograft nephropathy ("CAN") in the Banff schema. Am J Transplant, Vol., 7; pp. 518-526.

[92] Stegall, MD.; Diwan, T.; Raghavaiah, S.; Cornell, LD.; Burns, J.; Dean, PG., et al. (2011). Terminal Complement Inhibition decreases Antibody-Mediated Rejection in Sensitized Renal Transplant Recipients. Am J Transplant, Vol., 11; pp. 2405-2413.

[93] Stegall, MD. \& Gloor, JM. (2010). Deciphering antibody-mediated rejection: new insights into mechanisms and treatment. Curr Opinion in Organ Transplant, Vol., 15; pp. 8-10.

[94] Stegall, MD.; Diwan, T.; Burns, P., et al. (2009). Prevention of acute humoral rejection with C5 inhibition. Am J Transplant, Vol., 9 (s2):241. 
[95] Steinmetz, OM.; Lange-Hüsken, F.; Turner, JE.; Vernauer, A.; Helmchen, U.; Stahl, RA., et al. (2007). Rituximab removes intrarenal B cell clusters in patients with renal vascular allograft rejection. Transplantation, Vol., 84; pp. 842-850.

[96] Sumitran-Holgersson, S.; Wilczek, HE.; Holgersson, J. \& Soderstrom, K. (2002). Identification of the nonclassical HLA molecules, MICA, as targets for humoral immunity associated with irreversible rejection of kidney allografts. Transplantation, Vol., 74; pp. 268-277.

[97] Sureshkumar, KK.; Hussain, SM.; Carpenter, BJ.; Sandroni, SE. \& Marcus, RJ. (2007). Antibody-mediated rejection following renal transplantation. Expert Opin Pharmacother, Vol., 8; pp. 913-921.

[98] Takemoto, SK.; Zeevi, A.; Feng, S.; Colvin, RB.; Jordan, S.; Kobashigawa, J., et al. (2004). National conference to assess antibody-mediated rejection in solid organ transplantation. Am J Transplant, Vol., 4; pp. 1033-1041.

[99] Terasaki, P.; Ozawa, M. \& Castro, R. (2007). Four-year follow-up of a prospective trial of HLA and MICA antibodies on kidney graft survival. Am J Transplant, Vol., 7; pp. 408-415.

[100] Terasaki, PI. \& Ozawa, M. (2005) Predictive value of HLA antibodies and serum creatinine in chronic rejection: Results of a 2-year prospective trial. Transplantation, Vol., 80; pp. 1194-1197.

[101] Terasaki, PI. \& Ozawa, M. (2004). Predicting kidney graft failure by HLA antibodies: a prospective trial. Am J Transplant, Vol., 4; pp. 438-443.

[102] Thaunat, O.; Patey, N.; Gautreau, C.; Lechaton, S.; Fremeaux-Bacchi, V.; Dieu-Nosjean, MC., et al. (2008). B cell survival in intragraft tertiary lymphoid organs after rituximab therapy. Transplantation, Vol., 85; pp. 1648-1653.

[103] Tinckam, KJ.; Djurdjev, O.\& Magil, AB. (2005). Glomerular monocytes predict worse outcomes after acute renal allograft rejection independent of $\mathrm{C} 4 \mathrm{~d}$ status. Kidney Int, Vol., 68; pp. 1866-1874.

[104] Toyoda, M.; Petrosyan, A.; Pao, A. \& Jordan, SC. (2004). Immunomodulatory effects of combination of pooled human gammaglobulin and rapamycin on cell proliferation and apoptosis in the mixed lymphocyte reaction. Transplantation, Vol., 78; pp. 11341138 .

[105] Veale, JL.; Liang, LW.; Zhang, Q.; Gjertson, DW.; Du, Z.; Bloomquist, EW., et al. (2006). Noninvasive diagnosis of cellular and antibody-mediated rejection by perforin and granzyme B in renal allografts. Hum Immunol, Vol., 67; pp. 777-786.

[106] Veronese, F.; Rotman, S.; Smith, RN.; Pelle, TD.; Farrell, ML.; Kawai, T., et al. (2007). Pathological and clinical correlates of FOXP3+ cells in renal allografts during acute rejection. Am J Transplant, Vol., 7; pp. 914-922. 
[107] Vieira, CA.; Agarwal, A.; Book, BK.; Sidner, RA.; Bearden, CM.; Gebel, HM., et al. (2004). Rituximab for reduction of anti-HLA antibodies in patients awaiting renal transplantation: 1. Safety, pharmacodynamics, and pharmacokinetics. Transplantation, Vol., 77; pp. 542-548.

[108] Vogelbacher, R.; Meister, S.; Gückel, E.; Starke, C.; Wittmann, S.; Stief, A., et al. (2010). Bortezomib and sirolimus inhibit the chronic active antibody-mediated rejection in experimental renal transplantation in the rat. Nephrol Dial Transplant, Vol., 25; pp. 3764-3773.

[109] Waiser, J.; Budde, K.; Schütz, M.; Liefeldt, L.; Rudolph, B.; Schönemann, C., et al. (2012).Comparison between bortezomib and rituximab in the treatment of antibodymediated renal allograft rejection. Nephrol Dial Transplant, Vol., 27; pp. 1246-1251.

[110] Weinstein, D.; Braun, WE.; Cook, D.; McMahon, JT.; Myles, J. \& Protiva, D. (2005). Ultra-late antibody-mediated rejection 30 years after a living-related renal allograft. Am J Transplant, Vol., 5; pp. 2576-2581.

[111] Williams, JM.; Holzknecht, ZE.; Plummer, TB.; Lin, SS.; Brunn, GJ. \& Platt, JL. (2004). Acute vascular rejection and accommodation: Divergent outcomes of the humoral response to organ transplantation. Transplantation, Vol., 78; pp. 1471-1478.

[112] Worthington, JE.; McEwen, A.; McWilliam, LJ.; Picton, ML. \& Martin, S. (2007). Association between $\mathrm{C} 4 \mathrm{~d}$ staining in renal transplant biopsies, production of donor-specific HLA antibodies, and graft outcome. Transplantation, Vol., 83; pp. 398-403.

[113] Worthington, JE.; Martin, S.; Al-Husseini, DM.; Dyer, PA. \& Johnson, RW. (2003). Posttransplantation production of donor HLA specific antibodies as a predictor of renal transplant outcome. Transplantation, Vol., 75; pp. 1034-1040.

[114] Worthington, JE.; Martin, S.; Dyer, PA. \& Johnson, RW. (2001). An association between posttransplant antibody production and renal transplant rejection. Transplant Proc, Vol., 33; pp. 475-476.

[115] Wu, GD.; Jin, YS.; Salazar, R.; Dai, WD.; Barteneva, N.; Barr, ML., et al. (2002). Vascular endothelial cell apoptosis induced by anti-donor non-MHC antibodies: a possible injury pathway contributing to chronic allograft rejection. J Heart Lung Transplant, Vol., 21; pp. 1174-1187.

[116] Zachary, AA.; Kopchaliiska, D.; Montgomery, RA.; Melancon, JK. \& Leffell, MS. (2007). HLA-specific B cells. II. Application to transplantation. Transplantation, Vol., 83; pp. 989-994.

[117] Zachary, AA.; Montgomery, RA. \& Leffell, MS. (2005). Factors associated with and predictive of persistence of donor-specific antibody after treatment with plasmapheresis and intravenous immunoglobulin. Hum Immunol, Vol., 66; pp. 364-370.

[118] Zou, Y.; Stastny, P.; Süsal, C.; Döhler, B. \& Opelz, G. (2007). Antibodies against MICA antigens and kidney-transplant rejection. N Engl J Med, Vol., 357; pp. 1293-1300. 
